\title{
All's well? Comparing on- and off-site pollen samples and exploring the potential of pollen from man-made contexts
}

\author{
Yvonne F. van Amerongen ${ }^{1}$ D
}

Received: 29 March 2019 / Accepted: 3 November 2019 / Published online: 11 November 2019

(c) The Author(s) 2019

\begin{abstract}
Pollen analysis has long been used as a tool to make an assessment of regional vegetation. On-site pollen samples are taken for the same purpose at some excavations, because they are often the only available contexts with good preservation conditions. This paper shows that the analysis of on- and off-site pollen samples from the same region (West Frisia, the Netherlands) and time period (Dutch Bronze Age; ca. 2000-800 вс) can give very conflicting results on the type and amount of regional vegetation, in this case forest cover. Reasons for this discrepancy are discussed in relation to the use of on-site contexts by people in the past, as well as their location within a settlement. Furthermore, the potential of these contexts for the assessment of locally performed subsistence-related activities is outlined. New research directions are required to test this potential, so that wells and other man-made pollen traps can become a valuable future tool for reconstructing the past.
\end{abstract}

Keywords Pollen $\cdot$ Methodology $\cdot$ On-site contexts $\cdot$ Wells $\cdot$ Local and regional vegetation

\section{Introduction}

The use of pollen for vegetation reconstruction has a long research history going back to the first half of the 20th century. For such a reconstruction, some of the best sampling locations for pollen are natural, open locations such as mires, raised bogs, and lakes, since they give the most representative image of their surroundings due to a large diameter (Sugita 1994; Sugita et al. 1999), good preservation conditions, and a supposed low level of human disturbance.

In the Netherlands, such good sampling locations do exist, but are relatively rare in development-led excavations for several reasons. First, large areas of appropriate sampling locations/archaeological layers are strongly reduced due to (sub)recent disturbance by peat-cutting, construction work, etc. Second, a large part of the Netherlands consists of

Communicated by J. Lechterbeck.

Electronic supplementary material The online version of this article (https://doi.org/10.1007/s00334-019-00759-w) contains supplementary material, which is available to authorized users.

Yvonne F. van Amerongen

y.amerongen@archol.nl

1 Archaeological Research Leiden (Archol B.V.), Van Steenis Building, Einsteinweg 2, 2333 CC Leiden, The Netherlands
Pleistocene sand/loess subsoils with a (very) low water table, which means preservation conditions there are, in general, far from optimal (Fig. 1). Third, development-led archaeology focuses mostly on settlement sites, since that is where one can expect most finds. All these factors combined mean that not many features are available for pollen sampling in the sandy area of the Netherlands. These restrictions have resulted in a sampling strategy wherein mostly deep pits and/or wells can be sampled, since they usually are below the water table and have relatively good preservation. Interestingly, this also seems to have become common practice in locations where other features and better preservation conditions are available as well. The question is whether these on-site locations are appropriate locations to use for regional vegetation reconstruction, since they do not have a wide diameter and are man-made contexts that suffer from presumably high disturbance during and after use.

In this paper, the region of West Frisia in the Netherlands will be used as a case-study for the comparison of regional vegetation indicators in both on- and off-site pollen samples dating to the Dutch Bronze Age (2000-800 вс). The comparison between these samples shows a large discrepancy in forest cover indicators, affecting the interpretation of the openness of the landscape. Implications of using only on-site samples for vegetation reconstruction without the possibility for comparison with the off-site situation will be discussed, 


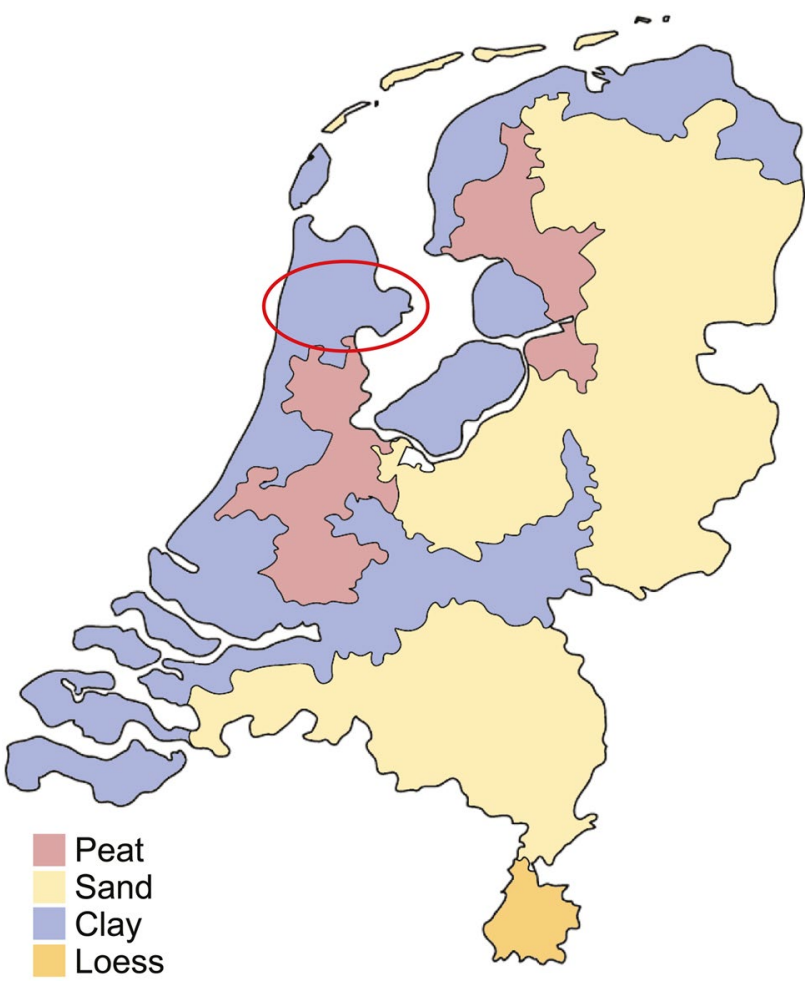

Fig. 1 Simplified map of the Netherlands with major subsoil categories (after Simplified soil map of the Netherlands, Alterra, Wageningen Environmental Research 2006) and the region of West Frisia indicated by a red circle

as well as ideas to improve upon the interpretation and merit of on-site samples in the future.

\section{Materials and methods}

\section{The region}

West Frisia is a region in the north-western part of the Netherlands (Fig. 1), of ca. $780 \mathrm{~km}^{2}$ that has distinct cultural aspects during the Dutch Bronze Age (the Hoogkarspel culture), such as different pottery styles, different house building traditions and different arable field systems to the Celtic field systems that occurred in the eastern half of Netherlands from $1300 \mathrm{BC}$ onwards (Arnoldussen 2018). It has excellent preservation conditions due to very heavy clayey subsoil and is also situated geographically between the Nordic and Atlantic exchange networks during this time period, which makes it a region that enables the study of many aspects of prehistoric life.

\section{The samples}

Specific information on the location and dates of the researched sites and samples is shown in Table 1. On-site pollen reports were collected from different developmentled archaeological excavation reports as well as standalone specialist reports.

Off-site pollen reports were collected at the TNO (Netherlands Organisation for Applied Scientific Research) in Utrecht, the Netherlands, which houses old surveying data collected by StiBoKa. StiBoKa is short for Stichting Bodem Kartering, an institution that was concerned with performing soil surveys during the second half of the 20th century before large scale re-allotments destroyed most of the topsoil
Table 1 Sampling information on both on-site and off-site pollen samples

\begin{tabular}{llll}
\hline Site name & Context type(s) & $\begin{array}{l}\text { Date (cal } \\
\text { Bc/climatic } \\
\text { period) }\end{array}$ & References \\
\hline $\begin{array}{l}\text { On-site samples } \\
\text { Medemblik }\end{array}$ & $\begin{array}{l}\text { Deep pit/well, ard marks, } \\
\text { settlement ditches }\end{array}$ & $1450-800$ & Kooistra (2010) \\
Zwaagdijk & Ditch & $1500-1100$ & van Zeist (1964) \\
Grootebroek & Burial mounds & $1500-1100$ & Waterbolk (1954) \\
$\begin{array}{l}\text { Hoogkarspel } \\
\text { Bovenkarspel }\end{array}$ & Burial mound & $1386-1025$ & Bakels (1974) \\
Enkhuizen & Deep pit/well and ditch & $1500-800$ & Buurman et al. (1995); van \\
Off-site samples & Ditch & $1500-800$ & Bos and Bouman (2011) \\
Warmenhuizen & Peat layer & (2012) \\
Zuid-Scharwoude & Peat layer & 1000 & Bakels (2005) \\
$\begin{array}{l}\text { Opmeer } \\
\text { Hoogwoud }\end{array}$ & Peat layer & Subboreal & Unpubl. StiBoKa data (ESM) \\
Medemblik & Peat layer & Subboreal & Unpubl. StiBoKa data (ESM) \\
Hoogkarspel Klokkeweel & Subboreal & Havinga et al. (1992) \\
Andijk & Peat layer & Subboreal & Unpubl. StiBoKa data (ESM) \\
\hline
\end{tabular}


in West Frisia. In order to prevent the risk of contamination by pollen from other locations, consulted pollen reports were only selected if they included a peat layer, and only samples that fell well within the boundaries of this layer were analysed further; peat layers that contained an admixture of minerals from clay or sand were therefore not included in the analysis. Furthermore, the sampled peat layer needed to date to the right time period. For some diagrams, radiocarbon dates were available, whereas other diagrams had to be analysed based on their specific pollen content to establish whether they dated to the Subboreal time period, which includes the Dutch Bronze Age. The transition from the Neolithic to the Bronze Age in the (northern) Netherlands is related to an increase in pollen of Fagus (beech) to about $1 \%$ which then becomes continuous, and consistently low percentages of Ulmus (elm) and Tilia (lime) (van Zeist 1959, p. 158; van Gijssel and van der Valk 2005). Since not every sampling location had enough samples to show diachronic changes throughout the Bronze Age, data of all layers per sampling location was averaged to accommodate a general Bronze Age comparison. Previously unpublished pollen data are available in the ESM.

\section{The analysis}

Data from both on- and off-site pollen samples were categorized into specific groups, each signifying a unique ecotype (i.e. general types of growth locations of plant communities). These groups are summarized in Table 2 .

The ecotypes allow for a separation of environmental indicators for trees versus an open landscape, wet versus dry conditions, saline versus non-saline conditions, and oligotrophic peat formation. The ecologically indeterminate group $(\mathrm{H})$ included taxa that could not be identified to the genus or species level. Furthermore, taxa that are not

Table 2 Ecotypes (groups) used for the pollen analysis for the reconstruction of the landscape

\begin{tabular}{ll}
\hline Unit & Vegetation type \\
\hline A & Upland* trees and shrubs \\
B & Wetland trees and shrubs \\
C & Upland* herbs \\
D & Salt marsh \\
E & Wetland herbs \\
F & Oligotrophic bog \\
G & Aquatic species \\
H & Ecologically indeterminate \\
\hline
\end{tabular}

*The term upland refers here to vegetation that needs rather dry conditions to grow and occurs in areas that are higher than wetlands. Since the Netherlands, and especially West Frisia, is flat, the variation in height between upland and wetland is usually very small $(1 \mathrm{~m})$, but can still give a distinctly different type of vegetation clearly specific for only one of the ecotypes, such as species belonging to the Cyperaceae family, were included here. Subsequently a pollen sum was created of the groups which signified regional vegetation (i.e. vegetation not present amongst the local eutrophic peat vegetation), including groups A, C, D, and F. Non-local vegetation growing under dry, saline, and/or oligotrophic peat, potentially present in the pollen record, could be identified in this way. Because in the applied method dryland vegetation was separated from wetland vegetation there was no interference from local wet trees and shrubs. This distinction allowed for an accurate assessment of the presence of upland vegetation in West Frisia (see Table 2 for explanation about the term upland).

The on-site pollen was analysed in exactly the same manner as the off-site samples. On-site pollen included both settlement and burial mound contexts. Although burial mounds are by no means necessarily located within a settlement, they are included under this category because they are part of the human activity realm, whereas (extensive) peat layers are natural phenomena that occur at off-site locations, or at least presumably in the absence of human activity.

\section{Results}

The results of both the on- and off-site pollen analyses are shown in Figs. 2 and 3, respectively. The on-site pollen deriving from settlement contexts generally demonstrate an open landscape consisting of mostly upland herbs (Fig. 2). In the past, the landscape of West Frisia has been reconstructed as a treeless, open landscape (Bakker and Brandt 1966 and references therein; Buurman 1996), predominantly based on these samples. However, some of the more recently analysed settlement contexts from Medemblik (Fig. 2, first diagram), as well as all the sampled burial mound-related contexts indicate a higher presence of trees in the surroundings. This new analysis of regional indicators seems to show that onsite pollen does reflect that trees grew in the surroundings of the settlements, although they do not appear to have been present in high numbers based on these results. At several (presumably) more peripheral locations, the presence of oligotrophic peat can be observed, such as in burial mound and ard mark contexts, but this seems largely absent within actual settlement contexts (e.g. pits, ditches). Finally, no clear indicators for saline conditions are present at any of the sites.

The off-site pollen analyses show almost the reverse image of the pollen from on-site locations (Fig. 3). Upland trees and shrubs constitute a large portion of every diagram, indicating that the surroundings of the Bronze Age settlements were indeed far from treeless. In several of the diagrams, indicators of oligotrophic peat were present, suggesting that this type of peat did exist in the further surroundings 


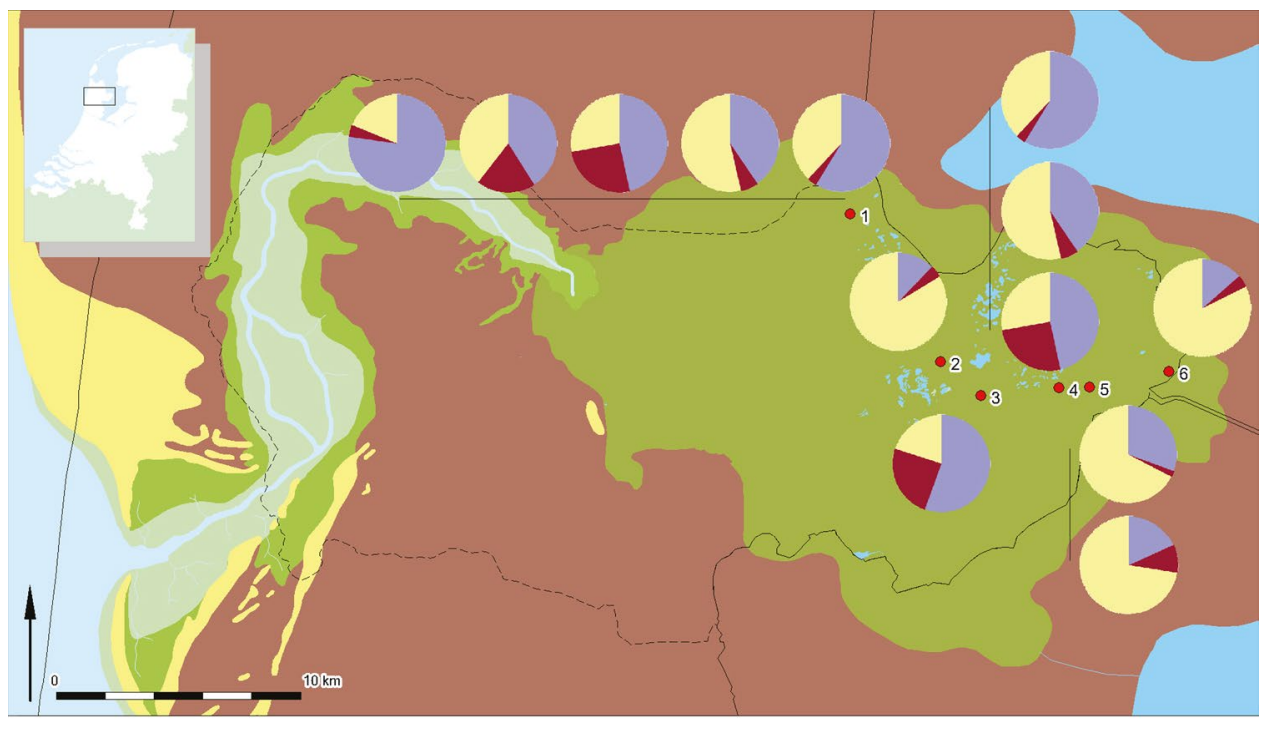

$\begin{array}{lllll}\text { - a } & \text { b } & \text { c } & \text { d }\end{array}$

Fig. 2 Indications for the regional landscape of West Frisia based on on-site pollen data. a Location of an excavated site; $\mathbf{b}$ upland trees and shrubs; c oligotrophic peat; $\mathbf{d}$ upland herbs; (1) Medemblik (from left to right: deep pit/well, $2 \times$ ard marks, $2 \times$ settlement ditches); (2) Zwaagdijk (ditch); (3) Hoogkarspel (burial mound); (4) Grootebroek (burial mounds); (5) Bovenkarspel (above: deep pit, below: ditch); (6) Enkhuizen (ditch). Legend to the underlying map: light yellow- low dunes; light green-intertidal areas (sand- and mudflats); mid green-fluvial flood plain and marine salt marsh areas; dark greenformer mudflats (now freshwater environment); brown - peat; light blue-mainly brackish and marine areas, North Sea, tidal channels and lagoons; bright blue-freshwater lakes; solid line-outline of the recent Netherlands; dashed line-outline of the recent area of West Frisia
Fig. 3 Indications for the regional landscape of West Frisia based on off-site pollen data. For the legend to the underlying map, see Fig. 1. a Location of an excavated site; $\mathbf{b}$ upland trees and shrubs; $\mathbf{c}$ oligotrophic peat; $\mathbf{d}$ upland herbs; e salt marsh. (1) Warmenhuizen; (2) Zuid-Scharwoude; (3) Opmeer; (4) Hoogwoud; (5) Medemblik;

(6) Hoogkarspel Klokkeweel;

(7) Andijk

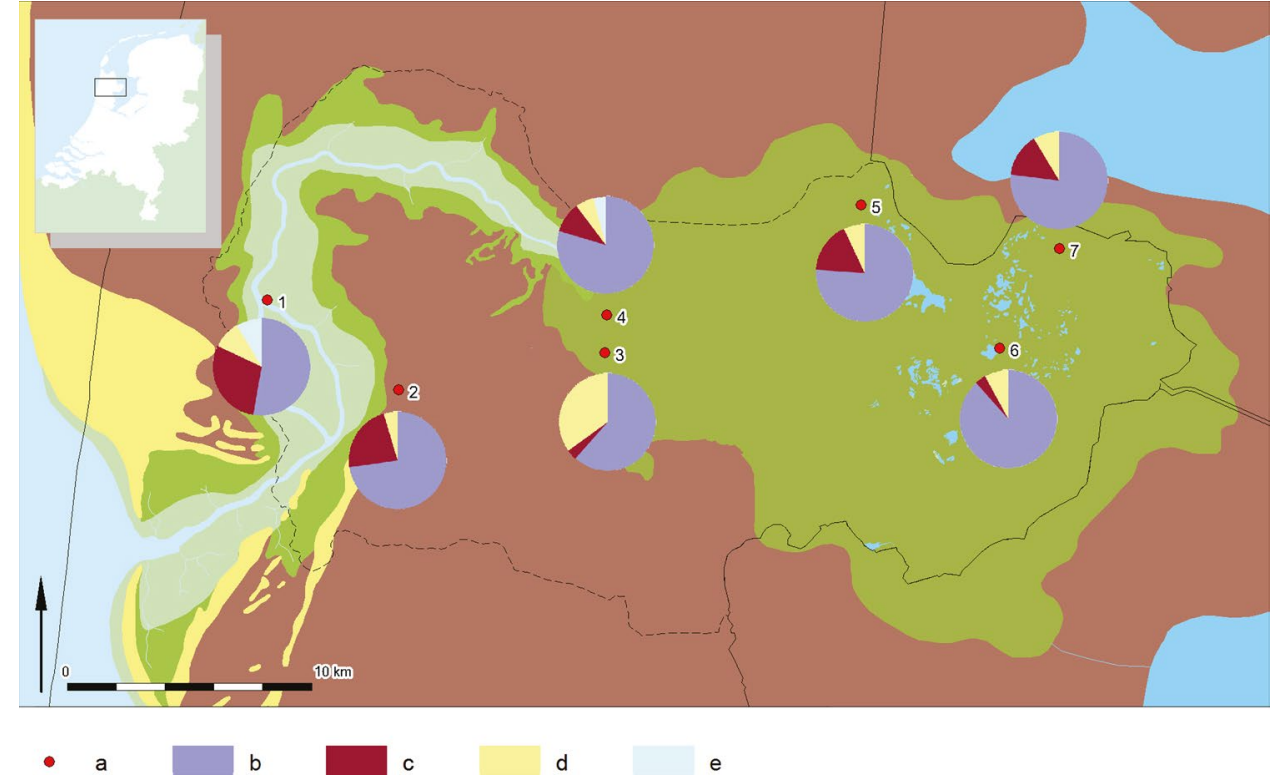

of the settlements, although nearly none were found within settlement contexts. Finally, indicators of salt marsh were mainly present in the western part, close to the intertidal area.

It is clear that the conclusions that can be drawn from the figures above are conflicting when each of the images is interpreted separately. Figure 2 shows the treeless landscape whereas Fig. 3 gives the impression of a forested environment, even within the same region and time period. So, when only on-site samples are available for analysis the obtained image of the surrounding landscape seems, at least in this case, misleading. 


\section{Discussion}

\section{Inherent problems with on-site contexts and especially wells for pollen analysis}

Why is it that on-site sampling locations appear to be so unfit for an accurate assessment of regional vegetation? Since the well or deep pit seems to be a popular sampling location for pollen because of good preservation conditions below the water table, we should consider these types of contexts in more detail. It then becomes clear that there are several factors and unknown variables that can potentially affect the results and interpretation of the pollen analysis for (regional) vegetation assessment. First of all, wells are sources of drinking water, which is a basic need in everyday life. This means that wells are generally kept close to the house. Since it is a basic need, drinking water is also very valuable. In order to keep this drinking water clean, wells are constructed with the prevention of contamination in mind. They often have an above-ground wall construction (e.g. made from mud, wood or bricks) to prevent or reduce contamination by surface debris and to prevent people and animals falling into the well; sometimes the well is additionally covered by a lid or small roof construction. The diameter of the well is variable and dependent on the number of people that need to stand inside the well during construction, but usually lies around $1 \mathrm{~m}$ (Wikiwater n.d.). When wells have been neglected for a while or work has been done to increase the yield through widening or lining the well, cleaning of the well is necessary. For traditional hand-dug wells this entails emptying the contents of the well, which usually includes sludge and debris, with for example buckets. During this procedure, the well walls can collapse if they are not lined or protected (Oxfam n.d).

All the factors outlined above, location near a house, closed construction, limited diameter, and human disturbance due to cleaning, all affect the entry and accumulation of pollen in the well.

When a well is close to a house, has an above-ground wall construction, and is covered by a lid or roof, the chance of pollen entering the well by wind is greatly diminished. The small diameter of the well furthermore results in a very small catchment basin for pollen which is not representative of regional vegetation (Sugita 1994; Sugita et al. 1999), even if the well was open and further away from the settlement. Sometimes the diameter of simple lined wells appears to be wider than $1 \mathrm{~m}$ during an excavation, but this is likely due to the gradual natural collapse of the wall of the well due to lowering of the water table, and does not represent the original diameter (Fig. 4).

This type of natural wall collapse as well as intentional cleaning or widening of the well results in a major admixture of soil and pollen from layers that are not contemporaneous with the habitation of the settlement. The pollen from this debris will therefore not represent local vegetation around the well at the time of use, let alone the regional vegetation.

Other features such as ditches can also be subject to cleaning/dredging. However, the chance of really old layers contaminating these contexts is lower than in a well (provided the ditch is less deep than a well), and they represent open contexts with a larger catchment basin than wells. They should in theory therefore be more representative of the surrounding vegetation. Still, as is clear from Fig. 2, even these types of contexts seem inappropriate for regional vegetation assessment due to their close proximity to the settlement.

Considering these problems with wells and other on-site contexts, and the results of the analysis of the West Frisian pollen, it is clear that these types of contexts are unfit for the assessment of regional vegetation without comparison with off-site locations. However, since these contexts are often all that is available, what can be done with the data that we do have? To investigate the potential of pollen samples from on-site contexts, and especially wells, it is important to know what layers are actually analysed and how the resulting analysis data should be interpreted.

\section{Potential of on-site contexts}

Wells and deep pits are often filled in with rubbish, soil or a combination of the two when they are excavated. This infill layer represents the final use of the well. Below this layer,
Fig. 4 Degradation of a well in sandy-clayey soil due to lowering of the water table (after Ofermat 1981)

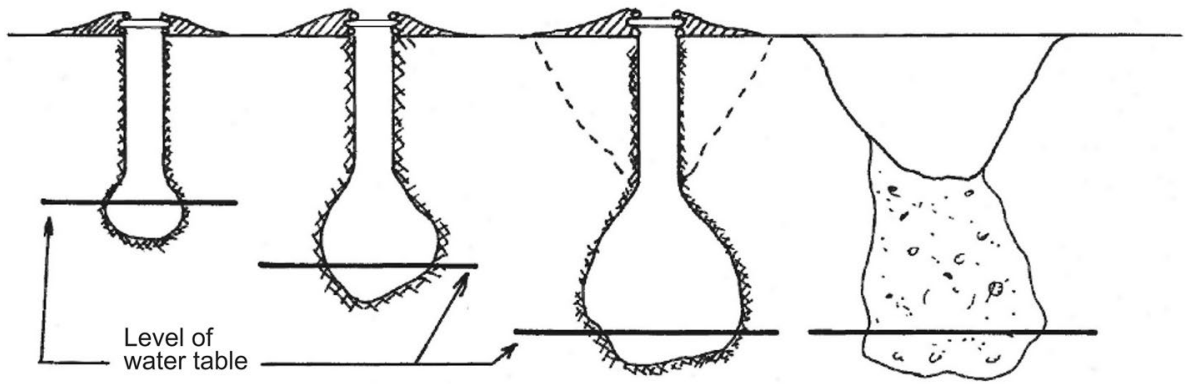




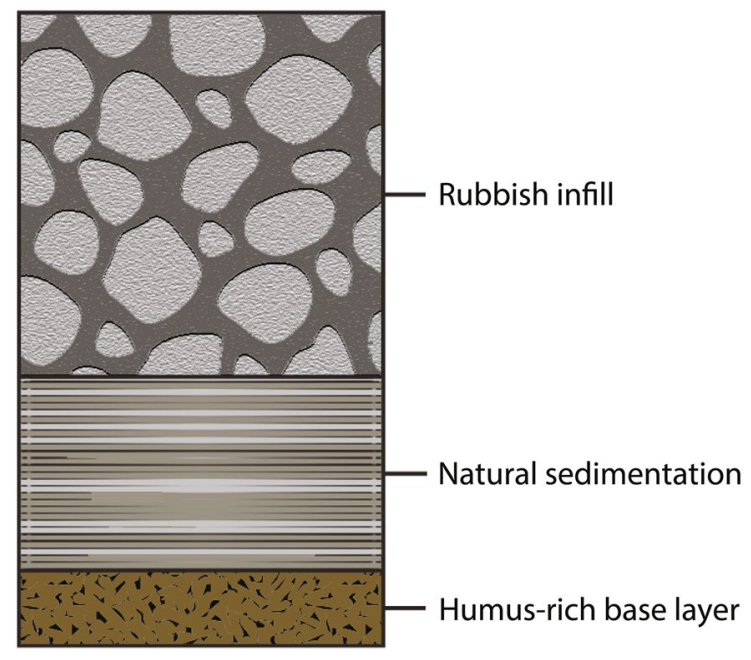

Fig. 5 Schematic representation of an excavated well fill

sometimes natural sedimentation layers occur and possibly a humus-rich layer at the base (Fig. 5), which are presumably least affected by the infill and might be related to initial use of the well. From Fig. 4 it is clear however, that even these layers may have originated from later periods of cleaning or from collapsed older sediment layers from the wall of the well. When pollen sequences of a well fill are analysed it is then very difficult to relate the finds to actual changes in time, since the stratigraphy might be inverted. It is therefore key that the correct layers are sampled and accurately dated to be able to assume contemporaneity of the well and the habitation phase.

What is also needed is an assessment of what is useful information that can be obtained from a man-made context. It can be imagined that air-borne pollen of wind-pollinated plants that have a high pollen production has a higher chance of being drawn into a well when it is opened than pollen from plants that have a low pollen production and are pollinated by insects. With this in mind it becomes possible to see man-made closed contexts as specific pollen traps for air-borne pollen that happens to be in the air around the well at around the time it is opened. Most of the time this will not give us the (new) information we want: grass (Poaceae) pollen signifies an open landscape and we can already assume that most settlements were not built in the middle of a forest. However, if air-borne pollen can give us information on the activities that took place around the house, then it becomes a valuable tool for interpretations that may not be possible based on other research proxies.

In this respect, it is interesting to note that recently research has been conducted on the release and deposition of pollen during different stages of a very common human activity in the past: crop cultivation and processing (Liu et al. 2018). Their study was aimed at understanding if and how pollen of buckwheat (Fagopyrum Mill.), an insectpollinated plant (i.e. low visibility in the pollen record), is released during growth, flowering, harvest, threshing, winnowing, sieving, and grinding. What the researchers found was that the pollen of buckwheat is only locally released into the air in very high amounts ( $>70 \%)$ during threshing and sieving of the crop (Liu et al. 2018). Therefore, when high amounts of buckwheat pollen is found in wells for example, it informs us about the specific activities that took place in the near surroundings of that context. A similar situation can be envisaged for the processing of cleistogamous wheat species and the presence of dung (e.g. based on the presence of airborne coprophilous fungal spores: Cugny et al. 2010 and references therein). This means that wells can in effect become time-capsules for the cultural landscape on the settlement rather than the natural landscape outside of it.

\section{Future research to assess the potential}

Future research should aim at researching and relating pollen (and spore) release and dispersal to their deposition in closed man-made contexts such as wells. There is a need for a comparative method for on-site samples, wherein different modern context types are analysed during and after use under a range of variables (e.g. closed-not closed, proximity to activity areas, different layers, etc.). Assessing the potential of pollen analysis of on-site contexts for the reconstruction of activities taking place in the vicinity of the well (crop processing, presence of livestock) will help us understand past subsistence on a more detailed level. Assessing the representation of local and regional vegetation in modern on-site contexts will provide us with a solid baseline for the interpretation of the landscape. In addition, the influence of contamination on on-site contexts will become apparent, and can be taken into consideration when analysing past contexts. Finally, research towards these factors will give insight into the possibilities and limitations of on-site pollen research, thus improving future sampling strategies through knowledge of the reliability of samples from different context types for different types of research question.

Acknowledgements I would like to thank Helen O'Brien for checking the text and Wilko van Zijverden for making the Bronze Age maps and for his ideas and suggestions.

Open Access This article is distributed under the terms of the Creative Commons Attribution 4.0 International License (http://creativeco mmons.org/licenses/by/4.0/), which permits unrestricted use, distribution, and reproduction in any medium, provided you give appropriate credit to the original author(s) and the source, provide a link to the Creative Commons license, and indicate if changes were made. 


\section{References}

Arnoldussen S (2018) The fields that outlived the Celts: the use-histories of Dutch later prehistoric field systems (Celtic fields or Raatakkers) in the Netherlands. Proc Prehist Soc 84:303-327

Bakels CC (1974) Enkele milieuaspecten van grafheuvel Ia te Hoogkarspel. West-Frieslands Oud en Nieuw 41:259-263

Bakels CC (2005) Palynologie: drie pollenspectra uit natuurlijke afzettingen onder de terp Hartendorp. In: Waldus W, Schabbink M (eds) Warmenhuizen Hartendorp. ADC Report 402. ADC ArcheoProjecten, Amersfoort, pp 36-38

Bakker JA, Brandt RW (1966) Opgravingen te Hoogkarspel III: grafheuvels en een terp uit de late bronstijd ten ZW van het Medemblikker Tolhuis (voorlopige mededeling). West-Frieslands Oud en Nieuw 33:176-224

Bos JAA, Bouman MTIJ (2011) Palynologisch onderzoek. In: Roessingh W, Lohof E (eds) Bronstijdboeren op de kwelders: Archeologisch onderzoek in Enkhuizen-Kadijken. ADC Monograph 11. ADC ArcheoProjecten, Amersfoort, pp 271-274

Buurman J (1996) The eastern part of West-Friesland in later prehistory: Agricultural and environmental aspects. Dissertation, Leiden University

Buurman J, van Geel B, van Reenen GBA (1995) Palaeoecological investigations of a Late Bronze Age watering-place at Bovenkarspel, The Netherlands. Meded Rijks Geol Dienst 52:249-270

Cugny C, Mazier F, Galop D (2010) Modern and fossil non-pollen palynomorphs from the Basque mountains (western Pyrenees, France): the use of coprophilous fungi to reconstruct pastoral activity. Veget Hist Archaeobot 19:391-408

Havinga AJ, van der Berg RM, van Saparoea RM (1992) Pollen and macrofossil analyses of a unique peat remnant of the former extensive peat bogs in West Friesland, The Netherlands: a detailed record of coastal raised bog formation. Veget Hist Archaeobot $1: 185-188$

Kooistra LI (2010) Botanische materialen. In: Schurmans MDR (ed) Een nederzetting uit de Midden en Late Bronstijd te MedemblikSchepenwijk II, gemeente Medemblik. Zuidnederlandse Archeologische Rapporten 40. ACVU-HBS, Amsterdam, pp 125-141

Liu Y, Shang X, Sheng P, Song G (2018) Pollen dispersal in traditional processing of buckwheat and its application in agricultural archaeology. Sci China Earth Sci 61:1792-1803
Ofermat (1981) Le point d'eau au village; manuel de formation des formateurs villageois, Illustrations du livret 2. CINAM Comité Interafricain d'Etudes hydrauliques. https://www.pseau.org/outil s/ouvrages/cinam_le_point_d_eau_au_village.pdf. Accessed 26 March 2019

Oxfam (n.d.) Technical brief: Repairing, cleaning and disinfecting hand dug wells. OXFAM http://www.oxfam.org.uk/resources/ downloads/emerg_manuals/draft_oxfam_tech_brief_wellcleaning.pdf. Accessed 26 March 2019

Pals JP, van Geel B, Delfos A (1980) Paleoecological studies in the Klokkeweel bog near Hoogkarspel (prov. of Noord-Holland). Rev Palaeobot Palynol 30:371-418

Sugita S (1994) Pollen representation of vegetation in quaternary sediments: theory and method in patchy vegetation. J Ecol 8:881-897

Sugita S, Gaillard MJ, Broström A (1999) Landscape openness and pollen records: a simulation approach. Holocene 9:409-421

Van Geel B, Meijer Y, Pals JP, de Sitter-Homans L (2012) Biologisch onderzoek van Bronstijdgreppels en middeleeuwse waterputten in Bovenkarspel. West-Frieslands Oud en Nieuw 7:125-137

Van Gijssel K, van der Valk B (2005) Aangespoeld, gestuwd en verwaaid: de wording van Nederland. In: Louwe Kooijmans LP, van den Broeke PW, Fokkens H, van Gijn AL (eds) Nederland in de prehistorie. Prometheus, Amsterdam, pp 45-74

Van Zeist W (1959) Studies on the post-boreal vegetational history of south-eastern Drenthe (Netherlands). Acta Bot Neerl 8:156-185

Van Zeist W (1964) In: Modderman PJR (ed) Middle Bronze Age graves and settlement traces at Zwaagdijk, Gemeente Wervershoof, Prov. North-Holland. Berichten ROB, Amersfoort, pp $28-29$

Waterbolk HT (1954) De praehistorische mens en zijn milieu. Dissertation, Groningen University

Wikiwater (n.d.) Hand-dug wells. E29 Technical sheet. https://wikiw ater.fr/e29-hand-dug-wells. Accessed 26 March 2019

Publisher's Note Springer Nature remains neutral with regard to jurisdictional claims in published maps and institutional affiliations. 